Cornell Law Library

Scholarship@Cornell Law: A Digital Repository

Cornell Law Faculty Publications

2-10-2006

\title{
Substitute Chancellors: The Role of the Jury in the Contest between Common Law and Equity
}

Bernadette A. Meyler

Cornell Law School, bernadette-meyler@lawschool.cornell.edu

Follow this and additional works at: http://scholarship.law.cornell.edu/lsrp_papers

Part of the Legal History, Theory and Process Commons

\section{Recommended Citation}

Meyler, Bernadette A., "Substitute Chancellors: The Role of the Jury in the Contest between Common Law and Equity" (2006). Cornell Law Faculty Publications. Paper 39.

http://scholarship.law.cornell.edu/lsrp_papers/39 


\title{
CORNell LAW SCHOOL
}

\section{Legal Studies ReseArch PAPER SERIES}

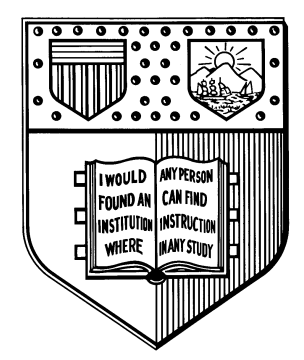

Substitute Chancellors: The Role of the Jury in the Contest between Common Law and Equity

\author{
Bernadette A. Meyler \\ Cornell Law School \\ Myron Taylor Hall \\ Ithaca, NY 14853-4901
}

Cornell Law School research paper No. 06-007

This paper can be downloaded without charge from:

The Social Science Research Network Electronic Paper Collection:

$\underline{\text { http://ssrn.com/abstract }=882829}$ 


\title{
SUBSTITUTE CHANCELLORS:
}

THE ROLE OF THE JURY IN THE CONTEST BETWEEN COMMON LAW AND EQUITY

\section{CONTENTS}

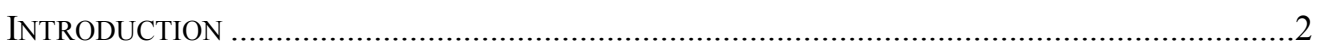

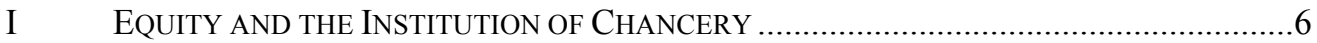

II Substantive Similarities: The Rhetoric OF EQUity AND CONSCIENCE .................11

III Procedural PARAdigms: FACt, LAW, AND Finality ............................................19

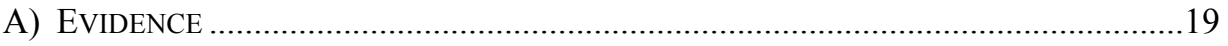

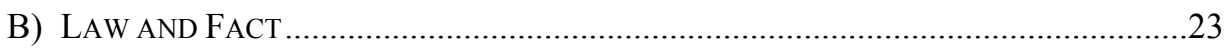

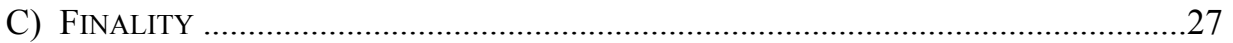

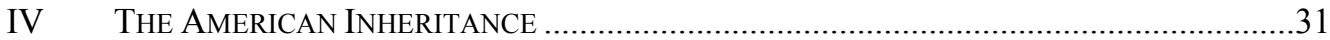

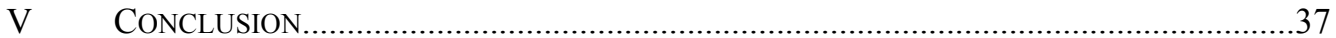

\begin{abstract}
The common law - thought to provide an "ancient constitution" securing the liberties of the people from monarchical tyranny - and opposition against it, played an acknowledged part in the debates among Royalists, Parliamentarians, and Puritans during seventeenth-century England. Very little attention has, however, been devoted to the status of the jury within these arguments either for the supremacy of the common law or for the King's prerogative, institutionally embodied most prominently in the Star Chamber and the Court of Chancery. As this Article argues, the procedural virtues and the philosophical goals of the jury and of the Chancellor as expressed by their advocates were very similar, but the disparities in the origins of their authority - the jury a body designed to represent local men of the community and the Chancellor considered almost a cipher for the King - led opponents in the English Revolution and its aftermath to resist
\end{abstract}


one institution or the other. Fluctuations in the relative strength and weakness of the common law jury and judges in equity thus came to depend on political struggles rather than disagreement about methods of adjudication. As a result, by the time of the Founding, opponents of the proposed Supreme Court expressed their reservations about its elevated status and its jurisdiction over "fact and law" by raising the specter of Chancery and its association with monarchical power.

\section{INTRODUCTION}

In 1616, Sir Edward Coke, Chief Justice of the King's Bench, whose stubborn advocacy on behalf of the common law lost him his official position, ${ }^{1}$ found himself able to analogize the discretionary capacity of the jury, chosen from the community, with the equitable powers of the Chancellor, appointed by the King, and claim that "the jury are chancellors." Responding to Coke's Institutes in the aftermath of the English Civil War, Thomas Hobbes, in his Dialogue Between a Philosopher and a Student of the Common-

\footnotetext{
${ }^{1}$ Coke's resistance to the jurisdiction of the Chancellor and his attempts to delimit the reach of Chancery were one of James I's principal reasons for removing him from office. See Roger Lockyer, The Early Stuarts: A Political History of England, 1603-1642 (London: Longman, 1989), 56-58.

${ }^{2}$ Hixt v. Goates and Fleetwood, 1 Rolle 257, 81 Eng. Rep. 472 (K.B. 1615). An agreement had been made between the plaintiff and the defendant about certain lands, by which the defendant stated that, if the land he had sold the plaintiff was less than he had calculated, he would pay the plaintiff eleven pounds per acre. The plaintiff alleged that the damages for such an underestimate were seven hundred pounds. However, the jury returned a verdict for the plaintiff of four hundred pounds. On appeal, the allegation was that "of necessity if as many acres were owed as the plaintiff argued, they [the jury] should find 7001. damage and if they did not find that as many were owed the verdict should not have been found for the plaintiff" ["de necessitie si tant acres deessent come le plaintiff ad allege ils duissoint trover 7001. damage et sils ne trove que tants deessent le verdict duissoit ester trove ver le plaintiff']. The reporter noted that, in his reply for the court, "Coke thought [the verdict] was fine since there were various reasons why in equity they [the jury] should not have given as great damages as that amount, since it seemed here that the jurors were chancellors" ["Coke semble est assets bon car poient ester divers causes pur que en equitie ils ne duissoint doner tant damages come ceo amount, car semble icy que le jurors fueront chancellors ...."']. The translations are mine.
} 
Lawes, published posthumously in $1681,{ }^{3}$ instead insisted on the equitable powers of the Chancellor as derived directly from the authority of the King and dismissed claims for the superiority of the jury at the same time as he rejected the priority of the common law.

Over a century later, a reporter on the debates leading to passage of the Judiciary Act of 1789, the first law to organize the courts of the new United States, hearkened back to Coke, insisting that "twelve honest jurors are good chancellors."4

The common law - thought to provide an "ancient constitution" securing the liberties of the people from monarchical tyranny — and opposition against it, played an acknowledged part in the debates among Royalists, Parliamentarians, and Puritans during the seventeenth century. ${ }^{5}$ While nascent civil libertarians and those agitating in the direction of democracy invoked the antiquity and immemoriality of the common law, the King and his supporters advocated viewing the law as derived from the monarch and his divine appointment. ${ }^{6}$ Very little attention has, however, been devoted to the status of the jury within these arguments for the supremacy of either the common law or the King's prerogative, institutionally embodied most prominently in the Star Chamber and the

\footnotetext{
${ }^{3}$ Thomas Hobbes, A Dialogue Between a Philosopher and a Student of the Common Lawes of England. 1681. Ed. Joseph Cropsey (Chicago: University of Chicago Press, 1971).

${ }^{4}$ Journal of William Maclay, United States Senator from Pennsylvania, 1789-1791. 1891. Ed. Edgar S. Maclay. (New York: D. Appleton and Company, 1890), 96.

${ }^{5}$ J.G. A. Pocock presented the classic exposition of the theory of the "ancient constitution" in The Ancient Constitution and the Feudal Law (Cambridge: Cambridge University Press, 1957). See also Glenn Burgess, The Politics of the Ancient Constitution: An Introduction to English Political Thought, 1603-1642 (Houndmills, Hampshire: Macmillan, 1992).

${ }^{6}$ According to Pocock: "Since there was an increasing tendency to claim sovereignty in the full sense for the king, it was natural that those who sought to defend threatened privileges or liberties should emphasize in return that their rights were rooted in a law which no king could invade.... The constitutionalists were therefore always being driven to argue that the laws were of a practically infinite antiquity, immemorial in the sense of earlier than the earliest king known." Ancient Constitution, 16-17.
} 
Court of Chancery. ${ }^{7}$ As this Article contends, the procedural virtues and the

philosophical goals of the jury and of the Chancellor as expressed by their adherents were

very similar, but the disparities in the origins of their authority — the jury a body designed

to represent local men of the community and the Chancellor considered almost a cipher

for the King - led opponents in the English Revolution and its aftermath to resist one

institution or the other. Fluctuations in the relative strength and weakness of the common

law jury and judges in equity thus came to depend on political struggles rather than

disagreement about methods of adjudication.

After briefly elaborating upon the conception of equity and the development of

Chancery in Part I, the Article turns, in Part II, to analyzing the rhetoric of conscience

and equity employed to describe the sources of both the Chancellor's and the jury's legal

decision-making. Part III then considers certain procedural resemblances between the

activities of the jury and the Chancellor. These include the respective modes of

evaluating evidence, the finality of each entity's verdict or judgment, and the assertion by

each of an ability—and, above all, a right — to decide both fact and law. Political

objections to vesting the capacity to determine the law as well as the facts in either the

${ }^{7}$ In The Law of Proof in Early Modern Equity, Michael Macnair suggests a connection between the ideological battles over the jury and those over equity jurisdiction in the seventeenth century, but does not elaborate the link. As he writes,

[T] he question of trial by jury was in the seventeenth century (as, indeed, later) a politically contested issue. Jury trial was, in fact, an aspect of the 'ancient constitution' ideology. In this context the events of 1640-60 and 1689 gave a substantial boost to the ... argument for the superiority of jury trial. The Chancery escaped abolition in the Civil War and Interregnum, but the other major English bill courts were destroyed and not restored. In this context an ideological shift towards 'juryism' may have been an element feeding in, together with the decline of examination on commission and the general shift towards a subjective standard of proof, to the expansion of the feigned issue procedure.

Michael R.T. Macnair, The Law of Proof in Early Modern Equity (Berlin: Duncker \& Humblot, 1999), 286. 
jury or the Chancellor were particularly strong. As Part IV demonstrates, at the time of the Founding, controversy over this issue continued unabated, although the target of censure became the Supreme Court, rather than Chancery.

The Article thus elucidates some of the reasons for the rise of one institution- the jury—over another — Chancery—and illuminates the implications of this displacement for the debates about the role of the Supreme Court in the federal judiciary of the United States. It also, however, suggests the fundamental resemblance between the type of discretion exercised by both judge and jury — in contrast with that employed by the legislative branch. ${ }^{8}$ Today, when the other branches are increasingly attempting to limit the scope of both judicial and jury decision-making, it is useful to recall that, historically, discretion may have been redistributed within the "judicial branch," but was not displaced outside it. ${ }^{9}$

\footnotetext{
${ }^{8}$ In The Bill of Rights, Akhil Amar explores the analogies between the respective places of judge and jury and those of the houses of the legislature proposed at the time of the Founding. See Akhil Reed Amar, The Bill of Rights (New Haven: Yale University Press, 1998), 104. Amar also contends that "the bicameral analogy is historically apt; it is anachronistic to see jury trial as an issue of individual right rather than (also, and more fundamentally) a question of government structure.” Ibid., 94-95. His account suggests the possibility of considering judge and jury together as forming a unitary "judicial branch."

${ }^{9}$ The Federal Sentencing Guidelines provide one of the principal examples of efforts to limit the scope of judicial branch discretion. Although the Guidelines were upheld against a separation of powers challenge in Mistretta v. United States, 488 U.S. 361 (1989), this decision focused not on whether the Guidelines deprived judges of discretion but instead on whether they derived from an unconstitutional delegation of legislative power to the Federal Sentencing Commission, an executive-appointed coalition of judges and others. In determining that the separation of powers had not been violated, Justice Blackmun's opinion noted that substantial discretion in sentencing had historically been accorded to judges. Id. at 363-64. By contrast, Justice Stevens, writing for the Court in Apprendi v. New Jersey, 530 U.S. 466 (2000), focused on the constraints historically imposed upon the judge's discretion in sentencing, $i d$. at 479; as a result, he held, in the context of a state statute, that any fact increasing the penalty for a crime above the prescribed statutory maximum must be submitted to a jury, and proved beyond a
} 


\section{Equity and the Institution of Chancery}

Historically, equity was thought to arise from the inherent prerogative of the

King, and simply to be embodied in the jurisdiction of the Court of Chancery, over which the monarchically selected Chancellor presided. ${ }^{10}$ In Chancery, unlike the Courts of King's Bench or Common Pleas, the Chancellor alone, in the absence of a jury, decided cases. Doing so, the Chancellor served as a substitute for the King himself; as one writer commented, "Nowe these things, which are donne in chauncerie, are not sayed to bee done before the chauncellor, but before the kinge himself, the chauncellor beinge there loco nomine et vice regia [in the kingly place and name]." $"$ The Court of Chancery possessed both an ordinary and extraordinary jurisdiction; as Coke wrote in his Fourth Institute, "In the chancery are two courts, one ordinary ... wherein the lord chancelour or lord keeper of the great seale proceeds according to the right line of the laws and statutes

reasonable doubt. $I d$. at 490. Although seemingly contradictory, with Mistretta emphasizing judges' discretion and Apprendi insisting instead on the constraints on such discretion, the historical accounts provided in the two cases can be reconciled; evidence for the different claims is simply derived from periods in which judge or jury enjoyed greater or lesser power. Conceptually, however, the conflict can most readily be resolved by first recognizing the historical struggle between judge and jury, then realizing that discretion resides in the judicial branch as a whole, rather than in either of its components to the exclusion of the other.

${ }^{10}$ The historical account contained in this paragraph is derived primarily from A.T. Carter, A History of the English Courts (London: Butterworth, 1927), 91-97.

${ }^{11}$ Anonymous, $A$ Treatise of the Maisters of Chauncerie, in A Collection of Tracts Relative to the Law of England, ed. Francis Hargrave (London: T. Wright, 1787), 293, 310. Although the author of the manuscript, which was found in the Inner-Temple library, remains unidentified, the editor speculated that the work was composed between 1596 and 1603 . William Lambarde provided a similar description of the derivation of the Chancellor's authority, writing that "such as then sought reliefe by Equitie, were suitors to the King himselfe, who being assisted with his Chancellor and Councell, did mitigate the severities of the Law in his owne person, when it pleased him to be present," and insisting that the Chancellor "is the Mouth, as it were, of the Prince." Archeion, or a Discourse upon the High Courts of Justice in England. 1635. Ed. Charles H. McIlwain and Paul L. Ward (Cambridge: Harvard University Press, 1957), 37, 39. 
of the realm .... Another extraordinary according to the rule of equity, secundem aequum et bonum [following the equal and the good]."12 In addition, it served early on as an officina brevium, or an office for writs, so that all the King's pardons - both general and special—-passed through Chancery, a circumstance consistent with the court's association with the mitigation of the rigors of the common law. Attempting to account for Chancery's capacity as an officina brevium, Lord Chief Baron Geoffrey Gilbert appealed to the interests of the King's prerogative:

The reasons of the institution of this officina brevium are many; first, that it might appear, that all power of judicature whatsoever flowed from the King, and therefore there was a summonce even to the peers in parliament, that sat in jure proprio; so likewise for the lower house of commons; the basis of the same was made by writs that issued out of this court, and were returned into the same office; and also in every judicature there were particular patents, which shewed the extent of their commissions, and that their power was derived from the crown. ${ }^{13}$

Early Chancellors were often religious figures rather than common lawyers, and exercised their jurisdiction both criminally and civilly. These ecclesiastical associations were thought to enhance the Chancellors' aptitude for their task; as William Lambarde commented in his Archeion, the Chancellor "(being commonly a Bishop, or other Spirituall person) was the more meet (after the opinion of men in those dayes) to give advice according to Equitie, and a good Conscience." ${ }^{14}$ The focus of Chancery gradually

\footnotetext{
${ }^{12}$ Sir Edward Coke, The Fourth Part of the Institutes of the Laws of England (London: A. Crook et al., 1669), 83. The Chancellor's extraordinary jurisdiction is the focus here. ${ }^{13}$ Lord Chief Baron Geoffrey Gilbert, The History and Practice of the High Court of Chancery (1758), 10.

${ }^{14}$ Lambarde, Archeion, 37.
} 
fell upon civil disputes, however, and, during the course of the seventeenth century, the

compass of cases over which the Chancellor could preside was circumscribed at the same time as common lawyers came to be appointed to the position. As a visible site of the King's sovereignty, like the Star Chamber, Chancery was almost abolished by the Parliamentarians during the English Revolution. ${ }^{15}$

Although Chancery survived all attempts against its continued existence, its power continued to diminish respective to that of the common law courts. The province of the jury, on the other hand, only increased. According to seventeenth-century common lawyers' understanding of the ancient constitution, jury trial and other due process rights preceded the Magna Carta, deriving their binding force not from that document but

${ }^{15}$ David Hume pointed out that "[s]ome steps were even taken towards an abolition of the chancery, the highest court of judicature in the kingdom." The History of England. 1773. (Indianapolis: Liberty Fund, 1983), vol. 6, ch. 61. One would-be judicial reformer, attempting to persuade Parliament that it should eliminate jury trials, also criticized the numerosity of courts, singling out the Court of Exchequer - another court of equitable jurisdiction-for special censure:

Particularly, to what purpose served the Kings Prerogative Court of Exchequer, one of the most eminent badges of Conquest and Tyranny? Surely all Courts, should be the Common-wealths in generall, and every mans in particular: Justice should not know any distinction of persons but be still one and the same in all Courts alike, whether as touching the letter of the Law, or Equity. Henry Robinson, Certain Considerations in Order to a more speedy, cheap, and equall distribution of Justice throughout the Nation. Most humbly presented to the High Court of Parliament of the most hopeful Common-wealth of England (London: Matthew Simmons, 1651), "Epistle Dedicatory." In his History of the Court of Chancery, Joseph Parkes provided a lengthy exposition of the judicial reforms attempted during the interregnum, focusing, in particular, on the attempts to abolish Chancery and subsequently to remedy perceived problems in its operations. Joseph Parkes, A History of the Court of Chancery (London: Longman, Rees, Orme, Brown, and Green, 1828), 129-92. 
instead from their immemoriality. ${ }^{16}$ By some accounts, jury trial itself was coextensive with the very concept of the common law. ${ }^{17}$

Early works on equity, including Edward Hake's Epieikeia ${ }^{18}$ and Christopher St. German's Doctor and Student, ${ }^{19}$ upon which Hobbes' later Dialogue was partially modeled, ${ }^{20}$ distinguished between equity as a general legal concept and as a practice of the Court of Chancery. The structure of Epieikeia demonstrates the breadth of Hake'sand, presumably, his contemporaries'-conception of equity. Divided into three parts, his dialogue treated first "Equity in General," then "The Equity of the Common Lawes of England" (including both case law and statutory interpretation), and finally (and rather briefly) "The Equity of the Highe Courte of Chancery." It proved advantageous,

\footnotetext{
${ }^{16}$ Thus, in The English-mans Right. A Dialogue Between a Barrister at Law, and a JuryMan, the Barrister responds to the question "how long trials by Juries have been used in this Nation?" by declaring "Even time out of mind; so long, that our best Historians cannot date the Original of the Institution, being indeed cotemporary with the Nation it self, or in use as soon as the people were reduced to any form of Civil Government, and administration of Justice." Sir John Hawles, The English-mans Right. A Dialogue Between a Barrister at Law, and a Jury-Man: Plainly Setting Forth: I. The Antiquity; II. The excellent designed use; III. The Office and just Priviledges of Juries by the Law of England (London: R. Janeway, 1680).

${ }^{17}$ Thus, Hobbes' Philosopher, in his Dialogue between a Philosopher and a Student of the Common-Lawes, inquires of the Student, while minimizing the importance of the jury, "perhaps you mean by Common-Law, not the Law it self, but the manner of proceeding in the Law (as to matter of Fact) by 12 Men, Freeholders, though those 12 Men are no Court of Equity, nor of Justice, because they determine not what is Just, or Unjust, but only whether it be done, or not done." Hobbes, Dialogue, 70.

${ }^{18}$ Sir Edward Hake, Epieikeia: A Dialogue on Equity in Three Parts (D.E.C. Yale ed., Yale Univ. Press, 1953). Initially written during the reign of Elizabeth I, the manuscript of this work was revised and presented to James I in 1604.

${ }^{19}$ Christopher St. German, Doctor and Student. 1530. Ed. T.F.T. Plucknett and T.L. Barton (Selden Society 1974), volume 91.

${ }^{20}$ It is possible that the other dialogues of the Restoration-like Hawles' The Englishmans Right, supra note 16, and Rudyard's Appendix by Way of Dialogue, infra note 64were likewise influenced in their structure by St. German's work. Hobbes' text, although constructed in dialogue form following St. German, is also patterned on the model of Coke's First Institute; not just countering Coke point by point, Hobbes further loosely followed the structure of Coke's treatise.
} 
however, for seventeenth-century supporters of monarchy to assimilate the philosophical advantages of equity as a mitigation of the law with the actual role of the Chancellor, whose power and prerogative derived directly from the King. Thus Sir Robert Filmer, in Patriarcha, against which Locke's Two Treatises of Government were directed, denigrated the due process rights secured by the Magna Carta —including the jury trial— and instead exalted the Chancery, arguing that "though the common law be generally good and just, yet in some special case it may need correction by reason of some considerable circumstance falling out which at the time of the lawmaking was not thought of. Also sundry things do fall out both in war and peace that require extraordinary help, and cannot wait for the usual care of common law ...."21 In prioritizing the institutional status of Chancery, Filmer even constructed an historical narrative associating the Chancellor intimately with the King:

As the judicial power of kings was exercised before the Conquest, so in those settled times after the Conquest wherein parliaments were much in use, there was a high court following the king, which was the place of sovereign justice both for the matter of law and conscience - as may appear by a parliament in King Edward I's time taking order 'that the chancellor and the justices of the bench should follow the king, to the end that he might have always at hand able men' for his direction in suits that came before him .... And this was after the time that the court of common pleas was made stationary, which is an evidence the king reserved a sovereign power by which he did supply the want, or correct the rigour of the common law, because the positive law, being grounded upon that which

${ }^{21}$ Sir Robert Filmer, Patriarcha. 1680. Reprinted in Patriarcha and Other Writings, ed. Johann P. Sommerville (Cambridge: Cambridge University Press, 1991), 1, 10. 
happens for the most part, cannot foresee every particular which time and experience bring forth. ${ }^{22}$

The King himself Filmer envisioned as an exalted version of the Chancellor, one who would exercise judgment in an analogous fashion, bound not by the common law but instead by his oath to exercise equity according to his conscience. As Filmer concluded, "[I]n effect the king doth swear to keep no laws but such as in his judgment are upright, and those not literally always, but according to the equity of his conscience joined with mercy, which is properly the office of a chancellor rather than a judge. ${ }^{, 23}$ If royalists insisted upon the association between equity and the institution of Chancery suggested by writers like Hake, advocates of the jury, by contrast, benefited from the early writings' elaboration of the principles of equity and applied them to the rhetorical advantage of jury trials.

\section{Substantive Similarities: The Rhetoric OF Conscience ANd Equity}

In what, then, did the conceptions of justice shared by proponents of the jury and Chancery consist? The most central terms were "equity" itself and "conscience." In both cases this "equity" was considered grounded in the law of reason, a type of natural law. A slight division arose over this issue, however, not between Chancery and the jury, but instead between advocates of the jury and writers on equity, on the one hand, and the judicial branch of the common law itself, on the other. Whereas common lawyers following in the footsteps of Sir Edward Coke believed that the law of reason was

\footnotetext{
${ }^{22}$ Ibid., 48-49.

${ }^{23}$ Ibid., 43. This emphasis on the oath as well as judging according to conscience is mirrored in contemporaneous writings on the jury. See infra, notes 43-44 and accompanying text.
} 
accessible primarily through accumulated precedent and the intricacies of the common law, those favoring equity as well as proponents of the jury preferred an untutored conscience. There arose thus an inadvertent convergence of arguments for the jury and for equity that circumvented the mediation of the ancient constitution and the common law.

Chancery as an institution was commonly dubbed the "Court of Conscience." As William West explained in The Second Part of Symboleography, "And for so much as this Court bridleth the rigour of the Common Law, by giving actions and exceptions for remedies where by Law none were, according to equity and conscience, to maintaine equum et bonum, the common people terme the Chancery the Court of Conscience; yet herein conscience is so regarded, that Lawes be not neglected, for they must joyn hands in the moderation of extremity." 24 In his treatment of Chancery, Hake had already announced that "it hath bin said that the essentiall parte required to be in the Lord Chauncellor is a good and sownde conscience," then proceeded to define conscience in detail, explaining its relation to the principles of reason. ${ }^{25}$ Equity itself he likewise connected with the law of reason, explaining that "[T]his Equity which is by some men called Epieikeia is no other thing but an exception of the lawe of God or of the lawe of Nature which is the lawe of Reason, from the generalitie of the lawe of man."26 Elaborating the meaning of the term conscience, St. German had written in Doctor and Student that "Conscience is an actuall applying of knowledge to some particular act of

\footnotetext{
${ }^{24}$ William West, The Second Part of Symboleography. 1590. (London: Miles Flesher and Robert Young, 1641), 176.

${ }^{25}$ Hake, Epieikeia, 130.

${ }^{26}$ Ibid., 13.
} 
man."27 Thomas Green has suggested in Verdict According to Conscience that tracts on the jury employed the same terminology, stating of the Levellers-perhaps the most radical of the groups involved in the English Revolution,- - that they "constantly invoked the notion of the 'reason' and 'equity' of the law" and also believed that, "Whether the jury acted on its own or at the behest of the bench, it applied the law according to 'conscience' in order to ensure that the defendant would receive his just deserts." 28 Discussions of conscience correspond to a sense both that the trier of factwhether jury or Chancellor-will make an individualized determination in each particular case, adjusting the mandates of common law precedents or statutory precepts to fit the situation, and that conscience will dictate mercy in certain circumstances where the penalty does not fit the crime. Although Hake viewed equity as ensconced within the law itself rather than emanating from the discretionary judgments of the Chancellor or jury, ${ }^{29}$ he explained in Epieikeia how the common law had come to contain certain exceptions to the application of its penalties based upon the defendant's lack of malice. These included exempting children who had committed felonies from the penalty of death, not

\footnotetext{
${ }^{27}$ St. German, Doctor and Student, 15.

${ }^{28}$ Thomas A. Green, Verdict According to Conscience: Perspectives on the English Criminal Trial Jury, 1200-1800 (Chicago: University of Chicago Press, 1985), 166-67. David Hume casts some light on the possible Puritanical leanings of juries during the period when he lists the names of members of a jury from Sussex during the Interregnum, all of whom had adopted religious sobriquets. Hume, History of England, vol. VI, ch. 61.

${ }^{29}$ Hake took the position that equity inhered in the law rather than in the probity of the individual pronouncing the law:

Nowe the onely matter in question between us is this, whether this Equity thus adhybited be the righteousnes of the judge or expositor of the lawe, or of the lawe itself. And, for myne owne opinion, I conceive it somewhat cleere that if the lawe we speake of be a good lawe and well grounded, then the Equity that must be used to the correction of the generalitye thereof cannot be said to be the Equitye of the judge, but of the lawe....

Epieikeia, 11.
} 
considering a wife guilty of robbery who has stolen on the command of her husband, and acquitting a man of burglary who has broken into a house to obtain food. ${ }^{30}$ Providing an alternative genealogy of similar provisions in the law, Greene has shown how thirteenthand fourteenth-century juries, which "acted upon their own extralegal notion of culpable homicide, ${ }^{31}$ created narratives that would subject certain defendants on trial for murder to a penalty lesser than death. On this account, the jury implemented the same equity that the common law came to acknowledge. The actual institution of Chancery retained some significance in this process as well; the "pardon of course" that defendants would receive after jury verdicts suggesting that they had operated in self-defense was, notably, processed through Chancery itself. ${ }^{32}$

References to "reason" in the context of equity and conscience were not, however, unambiguous. At the opening of the First Institute, Coke himself had explained the relationship between reason and the common law, maintaining that "Reason is the life of the law, nay, the common law itself is nothing else but reason."33 His next sentences demonstrated the appropriateness of the chapter title - "On the Study of the Law" - as he insisted on "an artificial perfection of reason, gotten by long study, observation, and experience, and not of every man's natural reason. ${ }^{\text {34 }}$ Coke likewise implicitly dismissed the suggestion that the King or Chancellor could simulate such an "artificial perfection of reason," writing that "if all the reason that is dispersed into so many several heads, were united into one, yet could he not make such a law as the law of England is; because, by

\footnotetext{
${ }^{30}$ Hake, Epieikeia, 60-63.

${ }^{31}$ See Green, Verdict According to Conscience, 35.

${ }^{32}$ See supra note 13 and accompanying text.

${ }^{33}$ J.H. Thomas, Systematic Arrangement of Lord Coke's First Institute of the Laws of England (London: printed by S. Brooke, sold by Butterworth, 1836), 1.

${ }^{34}$ Ibid.
} 
many successions of ages, it hath been fined and refined by an infinite number of grave and learned men ...."35 It is precisely against such a claim of the impossibility of replicating the law of reason through the exercise of individual conscience rather than accumulated learning that Hobbes argued in his Dialogue. First explaining that reason could not be sufficient to constitute law in the absence of authority- "It is not Wisdom, but Authority that makes a Law,"36 - he then asserted that "the Kings Reason, when it is publickly upon Advice, and Deliberation declar'd, is that Anima Legis [spirit of the law], and that Summa Ratio [highest reason], and that Equity which all agree to be the Law of Reason ....”37 By maintaining otherwise, Hobbes claimed, Coke had engaged in an understandable — but incorrect—attempt to aggrandize the power of the common law judges rather than to describe the true workings of the law. ${ }^{38}$ If, then, for Coke, the law of reason is enshrined in the ancient constitution and the common law, for Hobbes it becomes manifest in the decrees of the King's emissaries in equity.

This opposition between reason acquired through education and learning and a natural law of reason appeared in the context of debates over the status of the jury as well as arguments about the respective place of equity and the common law. Capitalizing on the momentum propelling judicial reform during the Interregnum, ${ }^{39}$ Henry Robinson had produced a tract addressed to Parliament urging, among other changes, abolition of jury trials. ${ }^{40}$ One of his grounds for criticism was the claim that "There is not a competent number of understanding and fit men to be had in the lesser Divisions of a County, for

\footnotetext{
${ }^{35}$ Ibid.

${ }^{36}$ Hobbes, A Dialogue, 55.

${ }^{37}$ Ibid., 62 .

${ }^{38}$ Ibid., 56.

${ }^{39}$ See supra note 15.

${ }^{40}$ Robinson, Certain Considerations, 2.
} 
tryall of all Causes upon all occasions. ${ }^{, 41}$ In responding to Robinson's pamphlet, and affirming the centrality of the jury trial to the rights of the Englishman, an importance emphasized by its inclusion in the Petition of Right, William Walwyn distinguished between conscience and understanding, and insisted that the former should be prioritized over the latter. ${ }^{42}$ As Walwyn wrote:

Indeed, understanding is in great reputation, and so is utterance too, but yet nothing is so precious as a true conscience; not such a one as is satisfied with, touch not, tast not, handle not; nor with saying Corbun: nor with observation of days and times, no nor with saying Lord, Lord; but with doing judgment and justice, in delivering the Captive, and setting the Oppressed free; in feeding the Hungry, clothing the Naked, visiting the Sick and the imprisoned; and in faithfully keeping all promises and compacts amongst men, without which civil societies cannot be maintained.

And certainly, any one that hath such a good Conscience, would make a Conscience of removing so ancient a Land-mark, which our fore-fathers have set, Job. 22. 28. and more of such good Consciences I believe are to be found amongst our ancient English Gentry, and other our Free-holders, than among our sharpsighted, smooth tongued Travellers; and such as (to the honour of our English nation) have in all times served their Country justly and faithfully, judging the causes both of rich and poor without fear or favour, as justly as can be expected

\footnotetext{
${ }^{41}$ Ibid., 2.

${ }^{42}$ William Walwyn, Juries Justified: Or, A Word of Correction to Mr. Henry Robinson; for His Seven Objections against the Trial of Causes, by Juries of Twelve Men (London: Robert Wood, 1651), 4-5.
} 
amongst men, yea, without respect to persons or opinions, as truly honouring God in their hearts, and trembling at an Oath taken to deal justly; and who with their lives and fortunes, in all times, have preserved this, the most essential Liberty of England. $^{43}$

Emphasizing the connection between the juryman's oath and the exercise of his conscience, Walwyn envisioned conscience both as involving a certain mitigation of positive law - through "setting the Oppressed free"- and as ignoring the status and place of those undergoing judgment and instead conducing to an impartial determination. Rather than considering the nuances of the law, the jury Walwyn contemplated should judge right and wrong with broad strokes. Addressing Robinson's claim that a few clever individuals dominate juries, Walwyn thus argued, "Nor is right and wrong so difficult to be discerned in Causes and Controversies, but that an ordinary capacity (careful to keep a good conscience, and that is tender of an oath) shall soon perceive the true state thereof; and be able to do right therein according to evidence." ${ }^{, 4}$

Early in the century, King James I had already voiced concerns about juries similar to those Robinson expressed, dismissing the idea that jurors lacking in understanding could still judge according to conscience. In his 1607 Proclamation for Jurors, James both lamented the quality of current juries and set forth plans for altering their composition. ${ }^{45}$ Beginning with a positive vision of the jury, James maintained that "it is then laudable and good, when those persons, which serve upon the said Juries, are men of such qualitie, credit and understanding, as are worthy to be trusted with so great a

\footnotetext{
${ }^{43}$ Ibid.

${ }^{44}$ Ibid., 9.

${ }^{45}$ King James I, Proclamation for Jurors (1607).
} 
charge, as to try mens lives, good names, lands and goods . ..."46 Associating such credit and understanding with class status, he then deplored the fact that:

Time and abuse have so embased the estimation of this service, and altered the use thereof, as Sheriffs, Undersheriffes, Bailiffes, and other inferiour Ministers, do not onely spare Gentlemen of qualitie, in a kinde of awe, and unwillingnesse to offend them, but do likewise for lucre, gaine and reward, forbeare to returne many of the ablest and fittest persons: So that the service often time resteth upon such as are either simple and ignorant, and almost at a loss in any cause of difficultie, or else upon those that are so accustomed and inured to pass and serve upon Juries, as they have almost lost that tendernesse of Conscience, which in such cases is to bee wished, and make the service, as it were an occupation and practice. ${ }^{47}$

Attempting to solve the perceived problem, James employed three devices: instructing his subjects that jury service is a great honor, and urging that "Gentlemen of best qualitie doe put away that vaine and untrue conceit, that they are any wayes disgraced, or disesteemed, if they be called upon or used in this part of Justice, to be tryers of the fact, Knowing that all Judgement is Gods principally, and by him committed unto us within the Precinct of our Kingdomes, as his Minister upon Earth, to whom likewise they are subordinate ${ }^{\text {"48 }}$; directing everyone involved in the judicial process to round up all freeholders for jury service - but to take care as well that no one be called too often; and, finally, assuring that he would grant a moderate number of exemptions to well-placed jurors in order to mitigate the effects of the change in policy. At the same time as

\footnotetext{
${ }^{46}$ Ibid..

${ }^{47}$ Ibid.

${ }^{48}$ Ibid.
} 
advocating for juries, James thus attempted to ensure that they would be composed of those upon whom - like the Chancellor-he would not be ashamed to place the imprimatur of his judicial power.

\section{Procedural Paradigms: Fact, LaW, and Finality}

Several other commonalities between the jury and the Chancellor depended on their modes of proceeding. It was part of the special capacity of the Chancellor that he could examine witnesses — including the defendant — under oath, and take into account circumstances outside the case. ${ }^{49}$ This investigatory power was paralleled by that of jurors taken from the vicinity, who had access to circulating rumors, as well as the witnesses to a crime. As Hobbes wrote, presumably against those who lauded the jury's ability to elicit evidence, "nor is a Jury more capable of duly examining Witnesses than a Lord-Chancellor." ${ }^{50}$ A correlate of this ability to make factual determinations was the jury's and the Chancellor's authority to decide cases on the basis of both fact and law. While opponents of the jury contested its capacity to interpret the law, enemies of Chancery rejected its fact-finding power. Finally, neither a general jury verdict for a defendant nor the Chancellor's decision was fully appealable.

\section{A) Evidence}

Seventeenth-century writers often noted the apparent disparities between the collection of evidence at common law and that practiced in equity. Recent work has

\footnotetext{
${ }^{49}$ A.H. Marsh, History of the Court of Chancery and of the Rise and Development of the Doctrines of Equity (Toronto: Carswell, 1890), 49.

${ }^{50}$ Hobbes, A Dialogue, 75.
} 
demonstrated that these divergences were not as vast as had earlier been supposed. ${ }^{51}$

Although the tradition of the self-informing jury had entered a period of relative disuse by the reign of James I, it still commanded nominal respect in Bushel's Case much later in the century, ${ }^{52}$ and provided an emphasis on collateral circumstances that was echoed in the Chancellor's capacity to look beyond facts of specifically legal significance. In addition, contemporaneous discussions about the grand jury suggested that it supplemented the evidentiary method of the petty jury, especially after the latter had ceased to be self-informing.

The Chancellor had at his command a variety of procedural devices that conduced to obtaining evidence: he could issue interrogatories, examine the defendant on oath, and subpoena witnesses. ${ }^{53}$ Although official recognition of his authority to employ these techniques differentiated his fact-finding capacity from that of the jury, one can envision the jury attaining similar results through a less formal method of investigation. During the period when the jury was self-informing, jury members might of their own accord

\footnotetext{
${ }^{51}$ Michael R.T. Macnair has argued that "The intervention of courts of equity may ... have furnished an important pressure driving the development of rules of evidence to a jury at common law." Macnair, Law of Proof, 288. In the effort to explain why, despite increasing congruencies between evidentiary practices in equity and common law during the seventeenth century, lawyers and tract writers continued to insist upon the differences, he writes that:

$[\mathrm{T}]$ he question of proof rules became intimately connected with more general debates about the 'ancient constitution' and the role of the jury. Connecting the question of proof/evidence in this way with the political-ideological debate over the jury helps ... with the chronology of relations between equity and law; it is at the same period, the later seventeenth and early eighteenth century, at which a connection to political history would lead one to expect an ascendancy of 'common law' ideology, that we also find the first assertions that equity follows the law in relation to witnesses ...."

Ibid.

${ }_{53}^{52}$ Macnair, Law of Proof, 21-22.

${ }^{53}$ See generally, Macnair, Law of Proof.
} 
independently examine witnesses not brought to court or assess the defendant's and plaintiff's reputations in the community. Likewise, while the defendant was not required or even allowed to give testimony under oath in the common law courts, the oath requirement in Chancery was displaced in King's Bench onto the jury members themselves as witnesses, who could be—and eventually were—severely punished for violating their oaths and not returning a true verdict. ${ }^{54}$

When the petty jury's self-informing quality had become nominal rather than actual, the grand jury became the repository of powers analogous to those of the Chancellor. Replying to tracts like Zachary Babington's Advice to Grand Jurors in Cases of Blood, ${ }^{55}$ which urged grand jurors to indict for murder-rather than a lesser charge - in all cases where one individual had killed another, John Lord Somers, who, not incidentally, became Chancellor during the reign of William III, underlined the importance of the grand jury's investigatory role. ${ }^{56}$ Babington had insisted on a type of separation of powers between the grand and petty juries, urging the grand jury both to relinquish fact-finding to the petty jury and to refrain from making determinations of law, thereby leaving them to the judge. As he asserted,

\footnotetext{
${ }^{54}$ See Green, Verdict According to Conscience, ch. 6.

${ }^{55}$ Zachary Babington, Advice to Grand Jurors in Cases of Blood. Asserting from Law and Reason that At the King's Suit in all Cases (where a person by Law is to be Indicted for killing of another Person) that the Indictment ought to be draw for Murther, and that the Grand Jury ought to find it Murther, where their Evidence is that the Party intended to be Indicted had his Hands in Blood, and did kill the other Person (London: John Amery, 1677).

${ }^{56}$ Chancellor John Lord Somers, The Security of Englishmen's Lives; or the Trust, Power, and Duty of the Grand Juries of England, Explained According to the Fundamentals of the English Government (originally author anonymous) (London: T. Michel, 1681).
} 
Two Reasons principally moved me to this Undertaking; The one was, The great Contests and Differences I have too often observed between the Judges and Grand Jurors about finding of Bills in Cases of Blood, whereby the whole matter of Fact, with all its Circumstances, might receive its full disquisition in Court, and not in a Grand Juries Chamber; the Grand Jurors (as if they were Judges both of the Law and the Fact, which is sufficiently demonstrated in the ensuing Discourse they are of neither) finding the Indictment sometimes Manslaughter, when they should find it Murther, contrary to the sense and direction of the Learned Judge, and of the King's Council, whereby a Murtherer many times escapes.

The second Reason was, That if the Law were not determined in this point, betwixt the Judges and Grand Jurors, the Consequence must needs be, That Grand Jurors (that hear but one side) would in the end take the matter of Fact from the Second Jury, that are proper Judges of it, and should try it; and the matter of Law from that learned Judge, that should give the Judgment of Law upon it ...."57

Somers, by contrast, emphasized that the grand jurors, like petty jurors, must return an indictment upon their oaths, and that "as clear evidence must be required for an indictment as for a verdict, it is unreasonable to think that a slighter proof should satisfy the consciences of the greater jury, than is requisite to convince the less ..." ${ }^{58} \mathrm{He}$ suggested that, in fact, grand jurors should exercise even greater care than petty jurors since they are accorded more latitude in examining evidence; as Somers opined, "the

\footnotetext{
${ }^{57}$ Babington, Advice to Grand Jurors, "To the Reader."

${ }^{58}$ Somers, The Security of Englishmen's Lives, 75.
} 
greatest part of the burden ought to lie upon them that have the best opportunities of performing it." ${ }^{, 59}$ Enumerating the advantages that the grand jury possesses in this respect, Somers stated that, "They are not straitened in time; they may freely examine in private, without interruption from the council or court, such witnesses as are presented unto them, or they shall think fit to call; they may jointly or severally inquire of their friends or acquaintance, after the lives and reputations of the witnesses or the accused persons, and all circumstances relating unto the matter in question, and consult together

under the seal of secrecy." ${ }^{60}$ As the "absolute judges" of the witnesses' evidence, ${ }^{61}$ these grand jurors resembled the Chancellor, who could similarly inquire pro-actively into the veracity of the witnesses and the circumstances of the case. Thus with the decline in the self-informing quality of the petty jury, the grand jury appeared to take over its evidentiary role.

\section{B) Law and Fact}

As the vehemence of Babington's assertion that the grand jurors cannot be judges of fact and law suggests, debate was fierce over whether jurors could find law as well as fact during the second half of the seventeenth century. Thomas Green has demonstrated that, although the petty jury had previously exercised a de facto ability to determine law as well as fact — and hence to nullify — it was in tracts between the 1653 trial of Leveller John Lilburne and Bushel's Case in 1671, as well as the conclusions drawn from Chief Justice Vaughan's opinion in the latter case, that the issue was most thoroughly

\footnotetext{
${ }^{59}$ Ibid.

${ }^{60}$ Ibid., 75-76.

${ }^{61}$ Ibid., 25.
} 
theorized. ${ }^{62}$ Although Vaughan's opinion in Bushel's Case did not explicitly legitimize the jury's decision on law as well as fact, he argued from the jury's unquestioned right to find fact "that the judge was never in a position to say with certainty that a jury had found against either law or fact." ${ }^{, 63}$ Thus, even if not de jure permitted to determine law as well as fact, the jury again came to possess a definite de facto power to decide on the law. In asserting that the jury did, indeed, have this capacity, commentators took several different tacks. The one perhaps closest to Justice Vaughan's was to claim that the fact and the law were inextricably intermeshed, and that any attempt to dissociate law from fact would be misguided. In the Appendix by Way of Dialogue, in a Plain and Friendly Discourse between a Student in the Laws and Liberties of England, and a true Citizen of London, Sir Thomas Rudyard followed Coke in envisioning the law as a "superstructure of fact," claiming - through the character of the Student:

And said Learned Cook ... upon stating the Fact, or transgression, Law doth arise; yea, the Law doth grow out of the Root of the Fact. . . . Now the Jury being the sole Judges of Fact, and matter in issue before them, not finding the Fact on which the Law should arise, cannot be said to find against the Law, which is no other than a superstructure of Fact, Then to say that they have found against the Law, when no fact is found, is most impossible. ${ }^{64}$

This account thus imagined a verdict on the law as growing organically out of an adjudication of the facts.

${ }^{62}$ See Green, Verdict According to Conscience, chs. 5-6.

${ }^{63}$ Ibid., 201. Bushel's Case, 124 Eng. Rep. 1006.

${ }^{64}$ Thomas Rudyard, Appendix by Way of Dialogue, in The Second Part of the Peoples Ancient and Just Liberties Asserted in the Proceedings against, and Tryals of Tho. Rudyard (1670). 
If opponents of the jury were eager to demonstrate that it was permitted only to decide the facts, not the law, adversaries of Chancery criticized the equitable methods of fact-finding while acknowledging that the Chancellor could determine the law. ${ }^{65}$

Hobbes, in his Dialogue, voicing the view of those who advocated equity against the common law, maintained that one of the primary distinctions between the two was that the judge in equity could announce both the facts and the law, whereas the jury was limited to a declaration of the facts; as the Philosopher of the Dialogue argues, "In the Courts of Common Law all Tryals are by 12 Men, who are Judges of the Fact; and the Fact known and prov'd, the Judges are to pronounce the Law; but in the Spiritual Court, and Admiralty, and in all the Courts of Equity there is but one Judge, both of Fact, and of Law; this is all the difference." ${ }^{, 06}$ Proponents of both the jury and the Chancellor thus

\footnotetext{
${ }^{65}$ Macnair explains that "apart from the rather special question of sovereignty and princes legibus solutus, most of the evidence for serious controversy between common lawyers and civilians, and between common law and equity courts, concerns questions of procedure, like general citation, compulsion to confess and the secret examination of witnesses." The Law of Proof, 28. Reluctance to permit individuals like the Chancellor to assume the fact-finding function may have led to remarks during the period of the Founding suggesting that hearings in the Supreme Court - which some, especially AntiFederalists, conceived as a new version of Chancery - should incorporate trial by jury. Thus, at a debate in the Massachusetts Ratifying Convention, one speaker asked, "When people, in common language, talk of a trial at the Court of Common Pleas, or the Supreme Judicial Court, do they not include all the branches and members of such court - the jurors as well as the judges? They certainly do, whether they mention the jurors expressly or not." Debate in Massachusetts Ratifying Convention, 2 Elliot's Debates 109-14 (30 Jan. 1788). Likewise, the Federal Farmer stated, "Whether the jury trial is not excluded [from] the supreme judicial court, is an important question. ... By court is understood a court consisting of judges; and the idea of a jury is excluded. . . . however, under the exceptions and powers to make regulations, congress may, perhaps introduce the jury, to try the fact in most necessary cases." Federal Farmer, no. 3, Herbert Storing, What the Anti-Federalists Were For, in The Founders Constitution, ed. Philip B. Kurland and Ralph Lerner (Indianapolis: Liberty Fund, 2001), Storing 2.8.41(10 Oct. 1787).

${ }^{66}$ Hobbes, A Dialogue, 137.
} 
spoke in favor of their respective capacities to articulate the facts and the law, while critics attempted to undermine their right to one or the other determination.

Connected to the issue of whether the judge or the jury should find facts at common law was the relationship between the jury's special and general verdicts. As Coke had described the special verdict in his Institutes, it allowed the jury to present a decision on the facts to the judge and request that he apply the law to those facts:

Discretion ought to be thus described. Discretio est discernere per legem quid sit justum. [Discretion is to discern by law what is just] And this description is proved by the common law of the land, for when a jury doe doubt of the law, and desire to doe that which is just, they find the speciall matter, and the entry is, $E t$ super tota materia, etc. petunt discretionem justiciariorum [concerning all matters, they seek the discretion of the judges], and sometime, advisamentum et discretionem justiciariorum in praemissis, etc. [the advice and the discretion of the judges in what was sent before] that is, they desire that the judges would discern by law what is just, and give judgement accordingly. ${ }^{67}$

The writer of the Appendix by Way of Dialogue elaborated at length upon Coke's distinction between the general and the special verdict, explaining that many judges, despite claiming that jurors could not determine the law, refused to accept a special verdict and would instruct the jury to return to deliberation until it could reach a general verdict. ${ }^{68}$ When the Citizen inquires of the Student why this would be, he responds, "Because then they have your Oaths as well for Law as Fact, and if the Judgment be

${ }^{67}$ Coke, The Fourth Part of the Institutes, 41.

${ }^{68}$ Rudyard, Appendix by Way of Dialogue, 56-57. 
severe, it shall lie at your door." ${ }^{\prime 69}$ This answer suggests that if, in theory, judges scorned the claim that the jury could decide on the law, in practice, they preferred to abdicate responsibility and substitute the jury's exercise of rigor or leniency for their own. ${ }^{70}$

\section{C) Finality}

The indistinction in the relationship between law and fact in the jury's determination conduced pragmatically to the unappealability of a general verdict. Two strands of this issue bearing upon the relationship between jury trial and Chancery emerged during the seventeenth century and continued to retain significance through the period of the Founding. On the one hand, Lord Coke, among other advocates of the common law, emphatically insisted that verdicts reached at common law in courts of the King's Bench could not be revisited in equity—and likewise attempted to constrain within legal limits the royal power of pardoning exercised through Chancery. This concern reappeared in writings at the time of the Founding expressing fears about the Supreme Court's ability to hear appeals, worries voiced through derogatory comparisons

\footnotetext{
${ }^{69}$ Ibid., 57.

${ }^{70}$ Hawles, in The English-mans Right, similarly discussed the relationship between the jury's general verdict and its ability to decide on the law:

[T] hough the direction as to matter of law separately may belong to the Judg, and the finding the matter of Fact does peculiarly belong to the Jury, yet must your Jury also apply matter of Fact and Law together; and from their consideration of, and a right judgment upon both, bring forth their Verdict: For do we not see in most general issues, as upon not guilty, pleaded in trespass, breach of the peace, or Felony, though it be matter in Law whether the party be a trespasser, a breaker of the Peace, or a Felon; yet the Jury do not find the Fact of the case by it self, leaving the Law to the Court; but find the party guilty, or not guilty, generally. So as though they answer not to the question singly, what is Law; yet they determine the law in all matters where Issue is join'd. . . . Now do they not therein complicatedly resolve both Law and Fact?

Hawles, The English-mans Right, 11.
} 
of the planned Supreme Court with Chancery. ${ }^{71}$ On the other hand, seventeenth-century writers on both Chancery and the jury trial emphasized the finality of decisions - and, in particular, those of acquittal—in both contexts. Although juries during the seventeenth century began to experience increasing pressure to conform their verdicts to the judge's view of the case - either during the trial itself or through the threat of a subsequent accusation against them - these measures did not contradict but were rather symptomatic of the jury verdict's conclusive quality, and, in any event, were eliminated by the outcome in Bushel's Case, which affirmed the principle that jurors could not be coerced. $^{72}$

While Coke's efforts to delimit the scope of equity jurisdiction and protect common law courts from its interference were quite controversial when he articulated them, ${ }^{73}$ they elaborated a paradigm that became widely accepted later in the seventeenth century. ${ }^{74}$ As Coke specified in his Third Institute, explaining that an act codifying certain restrictions on equity jurisdiction merely cemented a long-standing tradition, "This court [of equity] cannot proceed in course of equity after judgment at the common law... And this is the ancient law at all times used, as this act speaketh." ${ }^{, 75}$ Among the reasons he adduced were the differences between the courts' methods of procedure, ${ }^{76}$ that the court of equity was not a court of record, ${ }^{77}$ and the interests of finality- that

${ }^{71}$ See infra, Section IV.

${ }^{72}$ See Green, Verdict According to Conscience, ch. 6.

${ }^{73}$ See supra note 1 and accompanying text.

${ }^{74}$ J.H. Baker, An Introduction to English Legal History (London: Butterworth, 1990), 126.

${ }^{75}$ Sir Edward Coke, The Third Part of the Institutes of the Laws of England (1797), 122.

${ }^{77}$ See supra notes 51-61 and accompanying text.

${ }^{77}$ One of the implications of this circumstance was that decisions in Chancery could bind only persons, not property. Coke, The Fourth Part of the Institutes, 3. 
[A]fter judgment the parties ought to be at peace and quiet, for judicia sunt tanquam juris dicta [judgments are, as it were, statements of the law], and if the party against whom judgment is given, might after judgment given against him at the common law, goe into court of equity for matter in equity, there either should be no end of suits, or every plaintif would leave the common law, and begin in the court of equity, whither in the end he must be brought, and that should tend to the utter subversion of the common law ... ${ }^{78}$

Coke did not explicitly mention the jury trial here-although his comments about equity courts' manner of examining witnesses recall arguments adduced for and against the jury's manner of proceeding — but later commentators have associated the finality upon which he insists with preservation of the jury's power to determine law and fact.

By 1681, John Lord Somers, who would himself become Chancellor under William III, was able to affirm the unappealability of jury verdicts, analogizing jurors to judges as Coke had identified them with Chancellors. As he maintained, "The office and power of these [petit] juries is judicial, they only are the judges, from whose sentence the indicted are to expect life or death: upon their integrity and understanding the lives of all that are brought into judgment do ultimately depend; from their verdict there lies no appeal: by finding guilty or not guilty, they do complicatedly resolve both law and fact." ${ }^{, 79}$ Subsequent to Bushel's Case, in which Chief Justice Vaughan had held that jurors could neither be fined nor imprisoned for their verdicts, the finality of the jurors' determination was reinforced by the principle that they could not be coerced in reaching

\footnotetext{
${ }^{78}$ Coke, The Third Part of the Institutes, 122.

${ }^{79}$ Somers, The Security of Englishmen's Lives, 4.
} 
it. ${ }^{80}$ In civil cases, a jury could be subject to attaint for reaching a false verdict. ${ }^{81}$ There seems to have been a general assumption by the time of the Restoration, however, that attaint was not applicable in criminal cases. ${ }^{82}$ It is worth noting that even in the civil context, no remedy was available in Chancery in cases of attaint; enumerating "certaine cases, wherein the partie grieved seemeth wronged in conscience, and yet is remedilesse in Chancerie" in The Second Part of Symboleography, William West included "a false verdict by a grand Jurie in Attaint. ${ }^{" 83}$ The jury verdict could thus be questioned, even in attaint, only by another jury, not by the King's power as embodied in Chancery.

As for the appealability of the decisions of the Chancellor himself, West affirmed that, "So great is the power, jurisdiction, and majesty of this Court, that Judgements therein given are not to be controuled or reversed in any other Court, then in the high Court of Parliament, which is the chiefest of all other Courts in this Realme." ${ }^{\prime 4}$ Even Parliament's capacity to hear appeals from Chancery—independent of the King's instruction, acknowledged as the ultimate authority behind even the Chancellor-was contested through the seventeenth century and not of ancient origin. ${ }^{85}$ Thus—

\footnotetext{
${ }^{80}$ See supra, note 54.

${ }^{81}$ Baker explains that 'An action called 'attaint' could be brought against jurors for giving a false verdict, and if it was successful the verdict would be quashed. But attaint did not permit judicial review of decisions of fact by way of appeal, to determine their substantial correctness, nor of rulings or directions in law by the trial judge. The only question was whether the jurors had perjured themselves, and the only evidence which could be considered in the attaint was that laid before the trial jury." Baker, An Introduction, 156.

${ }^{82}$ Green cites several tract writers for this proposition, as well as Chief Justice Vaughan's opinion in Bushel's Case. See Green, Verdict According to Conscience, 233 and 238.

${ }^{83}$ West, The Second Part of Symboleography, 179.

${ }^{84}$ Ibid., 177.

${ }^{85}$ In his extensive historical Preface to Lord Chief Justice Sir Matthew Hale's Jurisdiction of the Lords House, or Parliament, Considered According to Antient Records, Francis Hargrave explained that even in 1621 the Lords declined to exercise
} 
predictably, given the events of the century - as the jury's autonomy became increasingly impenetrable, the Chancellor's decisions became more and more subject to review.

\section{THE AMERICAN INHERITANCE}

The influence of these seventeenth-century discussions about the scope of the Chancellor's and the jury's authority manifests itself even in debates from the Founding Period over the jurisdiction that the future Supreme Court should exercise. Under Article III, the judicial power extends to "all Cases in Law and Equity," within the purview of the federal courts and the Supreme Court possesses "appellate Jurisdiction, both as to Law and Fact." ${ }^{\prime 86}$ These clauses — as well as the explicit, constitutionally enshrined protection for juries in criminal but not in civil cases - spawned considerable anxiety during the period leading up to ratification, and even subsequently during debates about the Judiciary Act of 1789. "Appeal" was, at the time of the Founding, understood by some as a civil law procedure, to be distinguished from the common law "writ of error."

appellate jurisdiction over decrees in equity and that they "then discerned the difference between exercising a general appellant jurisdiction over suits in equity under a claim of an authority inherent to their order, and exercising appellant jurisdiction over suits at law under the sanction and delegation of a writ of error issued by the crown." Lord Chief Justice Sir Matthew Hale, Jurisdiction of the Lords House, or Parliament. Ed. Francis Hargrave (London: T. Cadell and W. Davies, 1796). "Introductory Preface," xxvii.

${ }^{86}$ U.S. Const. art III, § 2, cl. 2.

${ }^{87}$ In the debates on the proposed constitution at the Pennsylvania Ratifying Convention, James Wilson argued against this view:

We are told, as an additional proof, that the trial by jury was intended to be given up; 'that appeals are unknown to the common law; that the term is a civil-law term, and with it the civil law is intended to be introduced.' I confess I was a good deal surprised at this observation being made; for Blackstone, in the very volume which the honorable member (Mr. Smilie) had in his hand, and read us several extracts from, has a chapter entitled 'Of Proceeding in the Nature of Appeals,'and in that chapter says, that the principal method of redress for erroneous judgments, in the king's courts of record, is by writ of error to some superior 
As Chief Justice Ellsworth explained in Wiscart v. D'Auchy (1796), “An appeal is a process of civil law origin, and removes a cause entirely; subjecting the fact, as well as the law, to a review and retrial: but a writ of error is a process of common-law origin, and it removes nothing for re-examination, but the law." ${ }^{, 8}$ Those with reservations about the Constitution — in particular, the Anti-Federalists — worried that introducing a system of appeal into the common law model would destroy the finality of the jury's determination of fact and thereby irreparably undermine the jury system. As the Federal Farmer lamented, "By the common law, in Great Britain and America ... juries are left masters as to facts: but, by the proposed constitution, directly the opposite principle is established. An appeal will lay in all appellate causes from the verdict of the jury, even as to mere facts, to the judges of the supreme court. Thus, in effect, we establish the civil law in this

"court of appeal." (3 Blackstone, 406.) Now, it is well known that his book is a commentary upon the common law. Here, then, is a strong refutation of the assertion, "that appeals are unknown to the common law." 2 Elliot's Debates 518 (11 Dec. 1787).

${ }^{88}$ Wiscart v. D'Auchy, 3 Dall. 321 (1796). For a general discussion of the derivation of the appeal as it was conceived in colonial America , see Mary Sarah Bilder, "The Origin of the Appeal in America," 48 Hastings Law Journal (1997): 913. As Bilder observes, "Three hundred years ago, the term 'appeal' referred to a legal procedure which was available only in the separate system of English courts governed by canon and civil law - and not in the common law system with which the Puritan settlers were so enamored. The legal procedure known as 'the appeal' did not refer to what we now think of as an 'appeal' - the correction by a higher court of errors of law made by a lower court. Instead, the 'appeal' referred to a procedure under which a higher tribunal could completely and broadly rehear and redecide not only the law, but also the entire facts of a case.” Ibid., 914. She also notes the seventeenth-century association between the appeal and proceedings in equity, stating that, "At the beginning of the seventeenth century, the word 'appeal' began consistently to appear in conjunction with discussions of the Chancery courts." Ibid., 934. 
point; for if the jurisdiction of the jury be not final, as to facts, it is of little or no importance." 89

While dismay was most palpable over appeal from jury determinations of fact, many critics of the system also insisted on the inseparability of law and fact within the jury's general verdict - a concatenation that contributed, in their view, to the inadvisability of permitting the Supreme Court to hear appeals. Speaking of civil casessince the Constitution did ensure a jury trial for criminal matters - the Federal Farmer asserted, "I hold it is the established right of the jury by the common law, and the fundamental laws of this country, to give a general verdict in all cases when they chuse to do it, to decide both as to law and fact, whenever blended together in the issue put to them. Their right to determine as to fact will not be disputed, and their right to give a general verdict has never been disputed, except by a few judges and lawyers, governed by despotic principles." ${ }^{90}$ The jury's right to arrive at a general verdict was especially important in the criminal context as it permitted a check on the tyrannical exercise of federal power. Its authority in reaching such a verdict would be negated by any appeal; even if the Supreme Court limited its review to points of law rather than fact, the jury would have to provide particulars of its holding that could be susceptible to review. As Brutus asserted,

${ }^{89}$ Federal Farmer, no. 15, Herbert Storing, What the Anti-Federalists Were For, in The Founders Constitution, ed Philip B. Kurland and Ralph Lerner (Indianapolis: Liberty Fund, 2001), Storing 2.8.189, 194 (18 Jan. 1788). The Federal Farmer was, historically, identified as Richard Henry Lee. In recent years, however, this association has been called into question. See generally, Robert H. Webking, "Melancton Smith and the Letters from the Federal Farmer," William \& Mary Quarterly 44: 3 (1987): 510.

${ }^{90}$ Ibid. 
I believe it is a new and unusual thing to allow appeals in criminal matters. It is contrary to the sense of our laws, and dangerous to the lives and liberties of the citizen. As our law now stands, a person charged with a crime has a right to a fair and impartial trial by a jury of his country, and their verdict is final. If he is acquitted no other court can call upon him to answer for the same crime. But by this system ... [the] whole matter may have a second hearing. By this means, persons who may have disobliged those who execute the general government, may be subject to intolerable oppression. ${ }^{91}$

In attempting to avoid these consequences of the Supreme Court's appellate jurisdiction, one writer even suggested permitting a jury determination of facts at the level of the Supreme Court. ${ }^{92}$ A passage from the Federal Farmer, however, dismissed this possibility as impracticable: "I confess it is impossible to say how far congress may, with propriety, extend their regulations in this respect. I conceive, however, they cannot by any reasonable construction go so far as to admit the jury, on true common law principles, to try the fact, and give a general verdict. ${ }^{, 93}$

One critic, in analyzing the meaning of "appellate jurisdiction over law and fact," assimilated this judgment of fact and law with the procedure of Chancery, explaining that the capacity to appeal a jury's judgment of fact as well as legal determinations would

\footnotetext{
${ }^{91}$ Brutus, no. 14, Storing 2.9.168-85 (28 Feb.-6 Mar. 1788).

${ }^{92}$ See supra note 65 . Although the suggestion may seem bizarre to the contemporary reader, the use of juries on appeal was not unprecedented at the time of the Founding. Under some of the colonial systems, appeals involving a matter of fact required the presence of a jury. See Bilder, supra note 88, 954.

${ }_{93}$ See Federal Farmer, no. 15, (18 Jan. 1788), in The Founders Constitution, Storing 2.8.189, 194.
} 
radically reduce the protections for liberty enshrined in the institution of the jury trial. ${ }^{94}$ As he expostulated, using the rhetoric of equity to favor the jury trial rather than the "foreign" innovations represented by courts like Chancery:

The word appeal, if I understand it right, in its proper legal signification includes the fact as well as the law, and precludes every idea of a trial by jury - It is a word of foreign growth, and is only known in England and America in those courts which are governed by the civil or ecclesiastical law of the Romans. Those courts have always been considered in England as a grievance... . It is well known that the courts of chancery in England were formerly entirely in the hands of ecclesiastics, who took advantage of the strict forms of the common law, to introduce a foreign mode of jurisprudence under the specious name of Equity.... in fact, there can not be any thing more absurd than a distinction between law and equity.... At any rate, it seems to me that there is much more equity in a trial by jury, than in an appellate jurisdiction from the fact. ${ }^{95}$

By thus associating appeals with Chancery and the determination of fact and law, he suggested how an institution like the Supreme Court could be seen as replacing the jury trial precisely because it would fulfill a comparable role.

Not simply content with opposing the idea of appeals and the Chancery model to the jury trial, he further criticized the status of the Supreme Court in a manner analogous to that in which some seventeenth-century commentators noted and disapproved Chancery's relation to the King's prerogative. Hypothesizing a situation in which federal officials would oppress local individuals, he wrote:

${ }^{94}$ A Democratic Federalist, Storing 3.5.5-9 (17 Oct. 1787).

${ }^{95}$ Ibid. 
Suppose therefore, that the military officers of congress, by a wanton abuse of power, imprison the free citizens of America, suppose the excise or revenue officers ...-that a constable, having a warrant to search for stolen goods, pulled down the clothes of a bed in which there was a woman, and searched under her shift,—- suppose, I say, that they commit similar, or greater indignities, in such cases a trial by jury would be our safest resource, heavy damages would at once punish the offender, and deter others from committing the same: but what satisfaction can we expect from a lordly court of justice, always ready to protect the officers of government against the weak and helpless citizen, and who will perhaps sit at the distance of many hundred miles from the place where the outrage was committed $?^{96}$

Institutionally, the Supreme Court resembled Chancery in its affiliation with a centralized government rather than local self-determination, and, like Chancery, it was located some distance away from the site of most cases it would adjudicate. Although the Supreme Court was not envisioned as a second Chancery for long, the eventual disappearance of the association may speak more to the power of naming than to the distinctions between the institutions.

The Judiciary Act of 1789 may itself be partly responsible for mitigating fears about the Supreme Court's exercise of jurisdiction. Under the Act, use of the "writ of error" rather than the appeal as the mechanism for reviewing lower court decisions ensured that the Supreme Court would not revisit the facts of a particular case. ${ }^{97}$ Senator

\footnotetext{
${ }^{96}$ Ibid.

| ${ }^{97}$ See Hart \& Wechsler, The Federal Courts and the Federal System (Richard H. Fallon, Daniel J. Meltzer, and David L. Shapiro eds., 4th ed. 1996), 32: "In all cases within the
} Formatted: Indent: First line: $0 "$ 
Maclay's Journal recording the debates on the Act contains perhaps the most sustained set of objections to the use of equity from the vantage point of an impassioned defender of the jury. ${ }^{98}$ At one point a provision was introduced - although not ultimately included in the Act - providing "that suits in equity shall not be sustained in either of the courts of the United States in any case where a remedy may be had at law."99 Adducing the example of a man who had covenanted to convey land and died before performance, Maclay disputed the claim there could be no relief for the individual to whom the property had been promised except in Chancery. Instead, he argued that the parties would consent to a judgment and the sale of the lands, ${ }^{100}$ and, if they did not, a jury could remedy the situation — albeit by granting damages rather than specific performance-as easily as a Chancellor. As Maclay stated, after excoriating Chancery for its insular quality and remove from popular sovereignty, ${ }^{101}$ "in case they do not consent, twelve honest jurors are good chancellors, if not to give the land, at least to give the value of it." ${ }^{102}$ Maclay's adoption of Coke's comment in Hixt v. Goates that jurors are chancellors confirms the profound influence that the seventeenth-century commentary on the nature

Court's appellate jurisdiction, review was to be by 'writ of error.' The effect of this limitation 'was to eliminate all possibility of a second trial of the facts, by jury or otherwise,' in Supreme Court review."

${ }^{98}$ For an excellent discussion of Maclay's interventions in their entirety, see Julius Goebel, History of the Supreme Court of the United States: Volume I, Antecedents and Beginnings to 1801 (New York: Macmillan, 1971), 494-503.

${ }^{99}$ Maclay, Journal, 95.

${ }^{100}$ Ibid.

${ }^{101}$ As Maclay observed, "as far as I knew the sentiments of the people of Pennsylvania, they disliked a chancery, but ... many of them knew not even the name." Maclay, Journal, 96.

${ }^{102}$ Ibid. 
of the jury and Chancery and the debate about their respective places had upon the

Founding generation and the allocation of jurisdiction. ${ }^{103}$

\section{CONCLUSION}

The seventeenth century contest between the jury and the court of conscience set the stage for William Blackstone's remark in his eighteenth-century Commentaries on the Laws of England lauding the trial by jury — especially in criminal cases - and insisting on the importance of protecting it against incursions by secret courts of conscience:

The trial by jury, or the country, per patriam, is also that trial by the peers of every Englishman, which, as the grand bulwark of his liberties, is secured to him by the great charter.... The antiquity and excellence of this trial, for the settling of civil property, has before been explained at large. And it will hold much stronger in criminal cases; since, in times of difficulty and danger, more is to be apprehended from the violence and partiality of judges appointed by the crown, in suits between the king and the subject .... Our law has therefore wisely placed this strong and twofold barrier, of a presentment and a trial by jury, between the liberties of the people, and the prerogative of the crown.... So that the liberties of England cannot but subsist, so long as this palladium remains sacred and

\footnotetext{
${ }^{103}$ At the time of the Founding, concern was also expressed lest the mode of interpreting the Constitution itself would be more equitable than legal. Gary McDowell has discussed the dynamics of this complaint in Equity and the Constitution, noting that "To 'Brutus,' the provision for the judicial power would allow judges to "explain the constitution according to the reasoning spirit of it, without being confined to the words or letter,' thereby granting them power 'to mould the government into almost any shape they pleased." Equity and the Constitution: The Supreme Court, Equitable Relief, and Public Policy (Chicago: University of Chicago Press, 1982), 6. Comments about equitable interpretation generally did not, however, invoke the jury.
} 
inviolate, not only from all open attacks, (which none will be so hardy as to make) but also from all secret machinations, which may sap and undermine it; by introducing new and arbitrary methods of trial, by justices of the peace, commissioners of the revenue, and courts of conscience. ${ }^{104}$

The stark opposition that Blackstone drew-a contrast relied upon by the Framers and others at the time of the Founding - derived not as much from inherent disparities in ideals and methods of adjudication as in a struggle for authority, one in which common law and jury were often, although not always, aligned against the power of the Chancellor, who represented the ineluctable and dreaded prerogative of the King. Precisely because advocates of both Chancery and the jury insisted upon their capacity to judge according to conscience rather than the intricacies of precedent or the letter of statutory law, neither trusted the others' exercise of such discretion, possibly believing that the oaths of the decision-makers were hardly sufficient to prevent abuse, or perhaps denying that the conscience of a Chancellor could be substantively the same as that of a jury. Whichever was the case, these legal combatants bequeathed upon the Founding generation an inheritance sufficiently ambiguous that most could be satisfied with enshrining the criminal trial jury while at the same time creating a Supreme Court that echoed Chancery in all but name.

${ }^{104}$ William Blackstone, Commentaries on the Laws of England, (1769), vol. IV, 342-44. 